\title{
Eläinaineksen hankinta laajentavalla lypsykarjatilalla
}

\author{
Leena Kärkkäinen ${ }^{1,2)}$, Ritva Hilpelä-Lallukka ${ }^{1)}$, Risto Kauppinen ${ }^{2)}$, Hannu Viitala ${ }^{2)}$, Hilkka Kämäräi- \\ nen $^{2)}$, Petri Kainulainen ${ }^{2)}$ \\ ${ }^{1)}$ Faba Jalostus osuuskunta, PL 40,01301Vantaa etunimi.sukunimi@,faba.fi \\ 2)Savonia ammattikorkeakoulu,PL 72,74101Iisalmietunimi.sukunimi@savonia.fi
}

\section{Tiivistelmä}

Maatalouden muuttuva toimintaympäristö on vaikuttamassa myös lypsykarjan eläinkauppaan. Aiemmin tuotantoa laajennettaessa eläinmäärä vakiinnutettiin uudelle tasolle oman karjan eläimistä. Tuotannon kaksin- tai moninkertaistuessa ja investointien suurentuessa ei voida jäädä odottamaan eläinmäärän kasvamista omasta aineksesta vaan eläinainesta on hankittava muilta tiloilta.

Eläinaineksen hankintaa tutkittiin haastattelemalla laajentaneita lypsykarjatiloja. Kyselyssä selvitettiin eläinaineksen hankintatapoja, -kanavia, eläinten hankintaikää ja karjanomistajien omia käsityksiä eläinaineksen hankinnan onnistumisesta. Kysely toteutettiin puhelinhaastatteluna 34 lypsykarjatilalle vuoden 2008 aikana. Tilat olivat eri puolilta Suomea.

Tämän tutkimuksen mukaan hiehon ostajat olivat merkittävästi tyytyväisempiä ( $\mathrm{P}=0,002$, Khiin neliö-testi) eläinten hankintatapaansa kuin vasikoiden ja lehmien ostajat. Suoraan tiloilta ostaneet olivat jonkin verran tyytyväisempiä ( $\mathrm{P}=0,035$, Khiin neliö-testi) eläinten hankintamenetelmäänsä kuin muita kanavia käyttäneet. Tutkimuksessa muita kanavia olivat Faba Jalostuksen NautaNetti, teurastamon vasikkavälitys, lehti-ilmoitukset, meijereiden tiedotteet, Internetin keskustelupalstat sekä huutokaupat.

Tässä tutkimuksessa selvitettiin lisäksi yhden esimerkkitilan avulla erilaisten hankintatapon tuotantokustannuksia. Kun ostettiin kolmen kuukauden ikäisiä vasikoita ja kasvatettiin ne vuokranavetassa, olivat tuotantokustannukset 2306 euroa eläintä kohti. Vasikoiden hankkiminen välityksestä ja kasvattaminen vuokranavetassa vähensi kustannuksia 235 euroa. Kasvatuskustannukset laskivat huomattavasti, kun vasikoiden kasvatus ulkoistetaan. Jos eläinten päivämaksu on 2,5 euroa, tulee tuotantokustannukseksi 1480 euroa. Kolmen euron päivämaksulla tuotantokustannus on 1662 euroa. Hiehojen ostaminen noin kolme kuukautta ennen poikimista, kuljettaminen ja kasvattaminen poikivaksi tekevät tuotantokustannukseksi 1906 euroa. Lehmiä ostettaessa tuotantokustannus on 1452 euroa eläintä kohti.

Tilan tuotanto-olosuhteilla ja yhteistyökumppaneilla on vaikutusta siihen, milloin laajentava tila eläimiä hankkii. Aiemmat kokemukset ja laskelmat auttavat valitsemaan omalle tilalle sopivan tavan. Tämän tutkimuksen tarkoituksena on tuottaa tietoa laajentavien tilojen eläinten hankinnan tueksi ja Faba Jalostuksen eläinkaupan kehittämiseen.

Asiasanat: nautaeläinten osto, laajentava lypsykarjatila, taloudellisuus 


\section{Johdanto}

Lypsykarjan eläinmäärän lisääminen isojen tuotantorakennusten rakentamisen myötä on muuttunut. Nykyisin karjamäärä voi kaksin- tai moninkertaistua. Karjan lisääminen omasta eläinaineksesta vähentämällä karsintaa veisi aikaa vuosia. Isojen investointien jälkeen navetta on saatava mahdollisimman pian täyteen tuotantoon. Investointi on saatava tuottamaan ja eläimiä on hankittava toisilta tiloilta.

Uutta eläinainesta voidaan hankkia pikkuvasikoina ja kasvattaa ne joko omissa tiloissa tai vuokranavetassa. Hoitajana voi olla karjanomistaja itse tai hoito voidaan ulkoistaa. Poikivia hiehoja voidaan ostaa tuotantorakennuksen valmistuttua tai kesällä laitumelle. Yksi mahdollisuus on ostaa poikineita lehmiä. Monessa tapauksessa käytetään näitä kaikkia tapoja resurssien mukaan.

Tutkimusteema on ajankohtainen työn tilaajalle, Faba Jalostus osuuskunnalle, nykyisin Faba Palvelu osuuskunta. Maatalouden toimintakulttuurin muutos vaikuttaa jalostuseläinkauppaan. Ennen asiakas halusi ostaa yhden eläimen, mutta nykyisin kysymys voi olla kymmenistä eläimistä kerralla.

Tämän tutkimuksen tavoitteena oli selvittää onnistuneen eläinkaupan edellytyksiä ja selvittää, mitkä tekijät edesauttavat ostoeläinten pysyvyyttä uudessa karjassa. Toisena tavoitteena on vertailla eri hankintamenetelmien taloudellisuutta. Tuloksia voivat hyödyntää niin Faba Jalostus osuuskunta kuin laajentava tila, joka harkitsee eläinten hankintamenetelmää.

\section{Aineisto ja menetelmät}

Erilaisia eläinaineksen hankintatapoja vertailtiin 34:1lä jo laajentaneella lypsykarjatiloilla. Hankintatapoja selvitettiin puhelinhaastatteluna toteutetussa kyselyssä, jossa haluttiin selvittää, millaisella eläinaineksen hankintatavalla onnistutaan saamaan laajentavalle tilalle hyvin sopeutuvia eläimiä, jotka kestävät karjassa hyvin. Tavoitteena on löytää tekijöitä, jotka laajentavan tilan on huomioitava ostaessaan vasikoita, hiehoja ja lehmiä.

Eläinaineksen hankintatavat tyypiteltiin viiteen ryhmään:1) Hankitaan vasikoita lihaeläinvälityksestä. Vasikat kasvatetaan itse vuokranavetassa tai siilossa tms. 2) Hankitaan vasikoita tai vuosikkaita. Kasvatetaan ne itse vuokranavetassa tai siilossa tms. 3) Hankitaan vasikoita tai vuosikkaita. Kasvatetaan ne vuokranavetassa. Hoitajana on tilan ulkopuolinen henkilö. 4) Ostetaan hiehoja uuden tuotantorakennuksen valmistuttua. 5) Ostetaan lehmiä uuden tuotantorakennuksen valmistuttua.

Alkuoletuksena oli, että monet eläinainesta hankkineet tilat ovat näiden viiden tyypin sekoituksia erilaisilla painotuksilla. Tarkoituksena oli löytää näitä kaikkia tyyppejä vähintään kolme jokaista.

Tutkimusmenetelmänä käytettiin kvantitatiivista eli määrällistä menetelmää. Osassa tutkimusta sovellettiin kvalitatiivista eli laadullista menetelmää, joka antaa syvällisemmän tarkastelukulman ilmiöön.

Kysely suoritettiin tammi-helmikuussa 2008. Haastattelukysymykset olivat strukturoituja eli vaihtoehtokysymyksiä. Vastaajilla on luettelo vaihtoehdoista. Näin haluttiin helpottaa kysymyksiin vastaamista ja vastausten analysointia. Vastaukset on analysoitu SPSS (versio 16.0.1)-ohjelmalla. Vastaukset ristiintaulukoitiin ja testattiin Khiin neliö -testillä. Merkitsevyysrajana käytettiin merkitsevyystasoa $\mathrm{P}<0,05$. Osa kysymyksistä on suunnattuja avoimia kysymyksiä. Näitä vastauksia on analysoitu litteroimalla ja luokittelemalla.

Mukana oli 34 laajentanutta lypsykarjatilaa eri puolilta Suomea. Tiloja oli maakunnittain lueteltuna Kainuusta, Pohjois-Pohjanmaalta, Keski-Pohjanmaalta, Etelä-Pohjanmaalta, Pohjois-Savosta, Etelä-Savosta, Kymenlaaksosta, Hämeestä, Pirkanmaalta ja Uudeltamaalta.

Erilaisia eläinaineksen hankintatapojen taloudellisuutta on vertailtu esimerkkitilan avulla. Aluksi laskettiin tilan tämän hetkinen hiehojen tuotantokustannus Kemppaisen \& Toroin (2008) laatiman hiehontuotantokustannuslaskurin avulla. Samalla laskurilla laskettiin esimerkkitilalle vaihtoehtoisten eläinten hankintatapojen tuotantokustannukset.

\section{Tulokset ja tulosten tarkastelu}

\section{Eläinten hankintamenetelmän valinta}

Haastatteluun vastaajista 35,3\% kertoi hinnan olleen eläinten hankintamenetelmään eniten vaikuttava tekijä. Laatu ja helppous olivat hankintamenetelmän valinnassa tärkein yhtä suuressa määrin eli 17,6 \%:lla. Hankintamenetelmän ratkaisi lopuilla vastaajista jokin muu tekijä. Nämä muut tekijät olivat seuraavanlaisia: ei tilaa vasikoille ja hiehoille, halutaan itse kasvattaa eläimistä sopivan kokoisia, 
pihattoon sopivia eläimiä, huutokaupat, mahdollisimman pian poikivia, läheltä, tarjontaa vasikoista kuivana kesänä rehupulan uhatessa, samasta paikasta useampia, lopettavia karjoja, käyttölehmiä, kultainen keskitie, nopeasti navetta täyteen, neuvoja valitsi, helppo tapa sekä tunnetuilta karjanjalostajilta.

Haastattelutiloista $47,1 \%$ oli pohtinut, mikä olisi eläinten kannalta paras hankintamenetelmä ja 44,1 \%, mikä olisi paras menetelmä eläinaineksen tason kannalta ajateltuna. Eläinten kannalta parasta hankintamenetelmää ja -aikaa kannattaa pohtia, jos haluaa eläinten sopeutuvan karjaan hyvin. Eläinaineksen taso näyttäisi monelta unohtuvan, kun hankintaan isoja eläinmääriä. Jalostuksellisesti korkeatasoisia eläimiä ei ole runsaasti tarjolla.

Alkionsiirtoa eläinaineksen parantamismenetelmänä oli käyttänyt 47,1 \% haastattelutiloista ennen laajennusta. Haastattelussa ei eritelty, onko tilalle tehty alkiohuuhteluja, -siirtoja vai molempia. Vain $14,7 \%$ oli käyttänyt alkionsiirtoa laajennuksen aikana. Laajennuksen jälkeen sitä oli käyttänyt yli puolet haastattelutiloista.

Joku haastatelluista piti erityisesti sukupuolilajitellun sperman ja alkionsiirron yhdistelmää hyvänä. Viiden haastatellun mielestä rakennushetkellä ei aika riitä keskittyä alkionsiirtoon. Seitsemällä haastatellulla oli raha esteenä. Viisi puolestaan kertoi oman stressin vaikuttavan eläimiin niin, ettei kiimoja tahdo muutenkaan silloin näkyä. Kuudella vastaajista oli joko omakohtaisia tai kuultuja huonoja kokemuksia, jotka estivät alkionsiirron käytön.

Alkionsiirron käyttäjien osuus haastatelluista oli reilusti enemmän kuin tuotosseurantatiloilla keskimäärin. Vuosien 2007 - 2008 aikana 9346 tuotosseurantatilasta on alkionsiirtoa käyttänyt 701 tilaa eli $7,5 \%$.

\section{Eläinaineksen hankinnan toteutus}

Haastattelutiloista $8,8 \%$ hankki eläinainesta ostamalla vasikoita teuraseläinvälityksestä ja kasvattamalla ne itse vuokranavetassa, siilossa tai vastaavassa. $35,3 \%$ hankki vasikoita tai vuosikkaita ja kasvatti ne itse. 26,5 \% hankki myös vasikoita tai vuosikkaita, mutta oli ulkoistanut kasvatuksen. 91,8 \% haastatelluista tiloista oli hankkinut siemennettyjä hiehoja laajennuksen valmistuttua. Osa näistä oli hankkinut siemennettyjä hiehoja jo ennen valmistumistakin laitumelle, jos laajennus oli ajoitettu valmistumaan syksyn aikana ennen talven tuloa. 67,7\% haastatteluista kertoi heille hankitun lehmiä laajennuksen valmistuttua. Lähes kaikki haastatellut olivat hankkineet eri-ikäisiä eläimiä.

Haastatelluista tiloista 79,4\% oli hankkinut ainakin osan eläimistä suoraan toiselta tilalta. Yhteydenottajana oli voinut toimia joko laajentaja tai lopettavan karjan edustaja. 11,8 \% tiloista oli hankkinut eläimiä teurastamon välityksen kautta. 61,8 \% vastaajista oli käyttänyt Faba Jalostuksen NautaNetti-eläinvälityspalvelua.

Muita kanavia käytti 32,4 \% haastatelluista. Näitä muita kanavia mainittiin olleen meijeritiedotteet, lehti-ilmoitukset, netin keskustelupalstat, huutokaupat, hiehon kasvattaja tai muu välittäjä.

Hankintatavan ratkaisevaksi tekijäksi vastaajat ilmoittivat $\mathrm{mm}$. tuotanto-olosuhteet. Tilalla ei ollut paikkoja tai muita resursseja hoitaa enempää eläimiä. Useampi haastateltava kertoi, että heille on suoraan tarjottu eläimiä ostettavaksi lopettavista karjoista tai sellaisilta tiloilta, joissa on ollut ylen määrin eläimiä omiin tarpeisiin. Useampi vastaaja kertoi resurssipulan takia antaneensa eläinaineksen hankinnan asiantuntijan hoidettavaksi.

$85,3 \%$ haastatelluista piti eläinten hankintatapaansa edullisena. 73,5\% piti eläinten hankkimismenetelmäänsä vaivattomana. Eläintautien suhteen pitivät hankintatapaansa turvallisena 79,4\% haastattelutiloista. Myyntikarjan ruokinnasta ja hoidosta otti selvää 70,6 \% vastaajista. Vajaalla kolmanneksella ei siis ollut käsitystä, miten eläimiä oli ruokittu ja hoidettu.

\section{Eläinaineksen hankinnan onnistuminen}

Haastattelutiloista $50 \%$ oli sitä mieltä, että heidän eläinaineksen hankintansa onnistui hyvin. Ne, jotka eivät osanneet vielä sanoa onnistumisesta, totesivat navetanvalmistumisesta olevan niin lyhyen ajan. Yli kaksi kolmasosaa haastatelluista totesi eläinten sopeutuneen hyvin uuteen karjaan. Niillä, joiden mielestä sopeutuminen oli vain kohtalaista, $20 \%: 1 l a$ syynä oli se, että eläimiä jouduttiin poistamaan. 60 \%:a mainitsi eläinten sairastelun ja lopuilla oli muita syitä. Eläimiä oli jouduttu poistamaan luonnevikojen, oksitosiinihormonin toiminnassa esiintyneiden häiriöiden sekä heikon utareterveyden takia. Sairauksista mainittiin utaretulehdus, ruokintaperäiset häiriöt ja sorkanvälitulehdus. Muita syitä olivat vedinpolkemat, stressi ja parsinavetasta tulleita jouduttiin taluttamaan. 
Vasikoita teuraseläinvälityksestä hankkineet olivat yhtä tyytyväisiä eläinten hankintatapaan kuin muilla tavoilla eläimiä hankkineet $(\mathrm{P}=0,19)$. On otettava huomioon, että vain $8,8 \%$ haastattelutiloista käytti tätä eläinten hankintatapaa. Muuta kautta vasikat ostaneista ja ne itse kasvattaneista olivat samoin yhtä tyytyväisiä eläinten hankkimistapaansa $(\mathrm{P}=0,24)$. Vasikkakasvatuksen ulkoistaneet olivat myös yhtä tyytyväisiä eläinten hankintatapansa kuin muut $(\mathrm{P}=0,73)$.

Hiehoja hankkineet olivat selvästi tyytyväisempiä hankintatapaansa kuin muilla tavoilla eläimiä hankkineet $(\mathrm{P}=0.002)$. Lehmänä eläinaineksen hankkineista koki onnistuneensa yhtä hyvin eläinten hankinnassa kuin muulla tavoin eläimiä hankkineet $(\mathrm{P}=0,48)$.

Suoraan tiloilta eläimiä hankkineet pitivät sitä hieman onnistuneempana kuin muilla tavalla eläimiä hankkineet $(\mathrm{P}=0.035)$. Teurastamon eläinvälityksestä eläimiä hankkineista kokivat eläinaineksen hankinnan onnistuneen yhtä hyvin kuin muilla menetelmillä $(\mathrm{P}=0,10)$. Faba Jalostuksen kautta hankkineilla $(\mathrm{P}=0.43)$ ja muita tapoja käyttäneillä $(\mathrm{P}=0,13)$ tulos on sama.

Hieman vajaa puolet haastatteluun osallistuneista oli sitä mieltä, että ostoeläinten sopeutuminen oli erilaista kuin heidän karjansa omien eläinten. Tähän saivat tilat antaa kommenttejaan. Niitä oli seuraavanlaisia: hankitut sopeutuivat paremmin, omat nupoutettuja - muut eivät, parsinavetasta tulevat ostoeläimet sopeutuivat hitaammin, ulkoiluttamattomat vaikeita, vaihtelevaa, vanhat käyttäytymismallit lehmillä ja vieras haju eri laumasta tulleilla.

Yli puolet haastatelluista oli sitä mieltä, ettei ostoeläinten sopeutuminen ollut erilaista. Heidän kommenttinsa olivat seuraavanlaisia: ostoeläimillä oli aikaa totutella puoli vuotta, ostohiehot omaan karsinaan, josta saivat haistella muita, pihatosta pihattoon ja useampi samasta paikasta kerralla. Samoin vajaat puolet olivat sitä mieltä, että eri karjoista tulevien eläinten sopeutuminen oli erilaista. Selityksenä näille haastateltavat kertoivat: aiemmat olosuhteet ja kohtelu vaikuttavat, eriluonteisia eri paikasta, hiehona tulleet eivät sopeutuneet, jostakin tuli pölkkyjä hiehoja, parresta tulleet stressasivat, robottinavetasta tulleilla sopeutuminen kaksi kertaa päivässä lypsyyn ja yhdestä karjasta huonoa ainesta.

Hieman vajaat puolet vastaajista oli sitä mieltä, ettei sopeutumisessa ollut karjakohtaisia eroja. Heidän kommenttejaan olivat seuraavat: hiehot kasvoivat samoista olosuhteista, mitä isommasta karjasta, sen parempi tulos; parresta parteen, pihatosta pihattoon, pihatosta parteen, tilaa väistää ja erot yksilökohtaisia, ei karjakohtaisia.

Mielenkiintoista näissä vastauksissa on hiehon ostajien ja vasikkana ostaneiden, mutta kasvatuksen ulkoistaneiden, hyvin erilainen näkemys eläinten sopeutumisesta. Voisi luulla olevan lähes sama asia ostaa hiehoja tai kasvatuttaa hankitut vasikat toisella. Vasikkakasvatuksen ulkoistajat joko luottavat ja tuntevat kasvattajan hyvin tai he kokevat tilanteen eri tavalla.

Vastaukset kysymykseen: "Oliko eri karjoista tulevien eläinten sopeutuminen erilaista?" olivat hyvin samansuuntaisia kuin edelliseen kysymykseen. Erityisesti hiehoina, mutta myös lehmänä eläinainesta ostaneet pitivät eri karjoista tulleiden sopeutumista erilaisena. Prosenttiluvut olivat 93,8 ja 87,5. Vasikkana ostaneiden mielestä eri karjoista tulevien sopeutumisessa ei ollut paljon eroa. Näissäkin vastauksissa vasikat itse kasvattaneet kokivat eroja olevan enemmän kuin vasikat teurasvälityksestä hankkineilla tai kasvatuksen ulkoistaneilla.

Haastattelutiloista 52,9 \% koki heidän karjansa jalostuksellisen tason pysyneen samana hankitulla eläinaineksella. 17,6 \% koki eläinaineksen tason parantuneen ja 29,4\% huonontuneen. Eläinaineksen tason nostamiseen laajennuksen yhteydessä eivät haastattelutilat näin ollen näyttäisi kovin paljon panostaneen tai sitten panostukset eivät ole tuottaneet tulosta.

Suoraan tiloilta eläinainesta hankkineista oli $22,2 \%$ sitä mieltä, että eläinaineksen tason parani. 29,6 \%:n mielestä se heikkeni ja 48,1 \%:n mielestä pysyi samalla tasolla. Teurasvälityksestä vasikoita hankkineista $25 \%$ oli heikkenemisen kannalla ja $75 \%$ sitä mieltä, että taso pysyi samana. Kukaan ei olettanut tason nousseen.

Faba Jalostuksen kautta eläinainesta hankkineista keskimääräistä useampi oli sitä mieltä, että eläinaines parani ja keskimääräistä vähemmän oli niitä, joiden mielestä eläinaines heikkeni. Muita väyliä käyttäneissä oli eniten niitä, joiden mielestä heidän eläinaineksen tasonsa heikkeni.

Eläinten hankintatavan suhteen oli eniten mielipiteitä eläinaineksen tason paranemisesta niillä, jotka olivat hankkineet vasikoita ja ulkoistaneet kasvatuksen. Samassa ryhmässä oli luonnollisesti vähiten niitä, joiden mielestä heidän karjan jalostuksellinen tasonsa heikkeni. Tämä selittynee sillä, että jalostuksellisesti korkeatasoisten vasikoiden hinta ei ole korkea, tai vasikan ostoon ollaan val- 
miimpia sijoittamaan kuin isompiin eläimiin. Lehmänä eläinaineksen hankkineissa oli eniten mielipidettä, että karjan jalostuksellinen taso olisi heikentynyt.

\section{Eläinaineksen hankinnan kustannukset}

Eläinaineksen taloudellisuutta vertailtiin tilamallilla, jossa on 30 lehmä- ja 40 nuorkarjapaikkaa käsittävä navetta. Navetta on 25 vuotta vanha ja sitä on laajennettu muutama vuosi sitten. Peltoa tilalla on yhteensä 96 hehtaaria, josta vuokrapeltoa 12 hehtaaria. Tilan vuonna 2010 suunniteltuun navetan laajennukseen tarvitaan nykyisen 30 lehmän lisäksi 40 eläintä. Eläinainesta voidaan hankkia erilaisilla menetelmillä ja eri-ikäisinä. Vertailua tehtiin vasikoiden ostamisesta ja niiden kasvatuksesta vuokranavetassa tai kasvatuksen ulkoistamisesta, hiehojen ostamisesta ja lehmien ostamisesta.

Kun ostettiin kolmen kuukauden ikäisiä vasikoita ja kasvatettiin ne vuokranavetassa, olivat tuotantokustannukset 2306 euroa eläintä kohti (KUVIO 1). Vasikoiden hankkiminen välityksestä ja kasvattaminen vuokranavetassa vähensi kustannuksia 235 euroa. Kasvatuskustannukset laskivat huomattavasti, kun vasikoiden kasvatus ulkoistetaan. Jos eläinten päivämaksu on 2,5 euroa, tulee tuotantokustannukseksi 1480 euroa. Kolmen euron päivämaksulla tuotantokustannus on 1662 euroa. Hiehojen ostaminen noin kolme kuukautta ennen poikimista, kuljettaminen ja kasvattaminen poikivaksi tekevät tuotantokustannukseksi 1906 euroa. Lehmiä ostettaessa tuotantokustannus on 1452 euroa eläintä kohti.

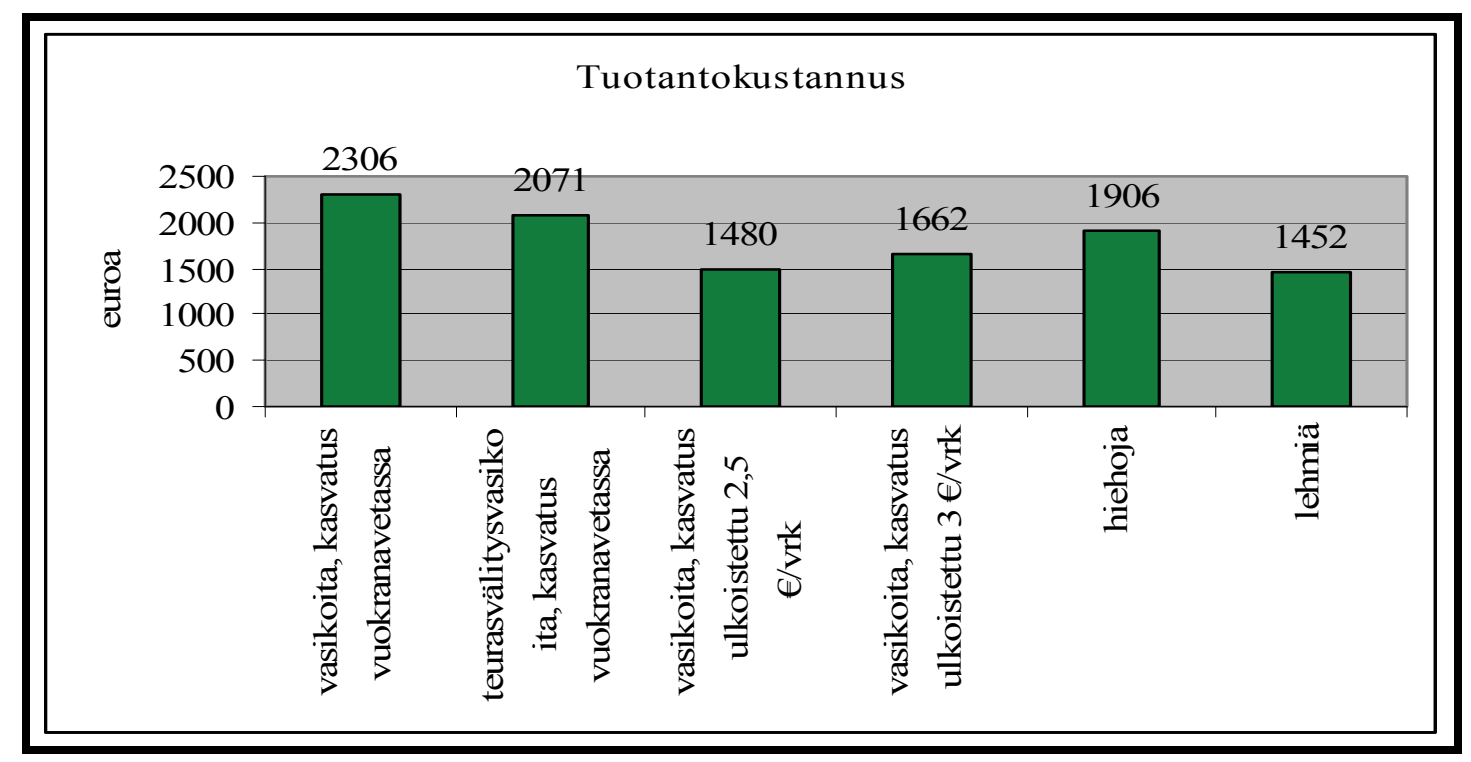

KUVIO 1. Erilaisen eläinaineksen hankintatapojen tuotantokustannusten vertailu

\section{Johtopäätökset}

Eläinaineksen hankinta laajentavalla tilalla on iso prosessi ja siihen kannattaa valmistautua huolellisesti. Tässä tutkimuksessa tehtyjen haastattelujen perusteella löytyi seikkoja, jotka helpottavat eläinten pysymistä uudessa karjassa.

Ostoeläinten sopeutumista helpottaa, jos myyjäkarjan olosuhteet ovat lähellä ostokarjan olosuhteita. Pihattokarjasta lähteneet taas sopeutuvat helpommin pihattoon. Pihatosta parsinavettaan ostettaessa ei sopeutuminen ole niin vaikea. Pihattoon parsinavetasta ostettaessa voi sopeutumista helpottaa ostamalla eläimet laidunkauden aikaan.

Tehtyjen haastattelujen perusteella voidaan todeta, että eläinaineksen hankkijat luottavat paljon hyvään onneen tarttuvien eläintautien suhteen. Pelkästään salmonella- ja BVD-tutkimuksilla saadaan vasta kapea näkemys myyjäkarjan terveydentilasta. Myyjäkarjan eläinlääkärin antama todistus antaa jo huomattavasti selvemmän tiedon karjan tarttuvien tautien tilanteesta.

Ostoeläimen sijoittaminen ensin sairaskarsinaan tai karanteeniosastolle helpottaa tautipainetta. Tautiriskiä pienentää myös eläinten ostaminen yhdeltä tai vain muutamalta pieneltä tilalta, johon ei ole ostettu vähään aikaan eläimiä. Sorkkien desinfiointi kuljetusautosta laskeutuneille eläimille voi auttaa sorkanvälin ajotulehduksen estämisessä. 
Hiehoja ostettaessa kannattaa varata riittävästi aikaa siirron ja poikimisen välillä. Siirron pitäisi tapahtua kolme kuukautta ennen odotettua poikimista.

Vasikoita puolestaan ei kannattaisi siirtää liian nuorena. Neljän kuukauden ikää pidettiin hyvänä siirtoikänä. Silloin vasikan ruokinta on jo vakiintunut eivätkä ruokinnan muutokset aiheuta sille stressiä. Vasikan vasta-ainetuotanto on jo hyvällä tasolla, jolloin se kykenee vastustamaan tarttuvia tauteja. Väliaikaistiloissakin vasikoilla pitäisi olla kunnon olosuhteet, jos halutaan kasvattaa niistä hyvinvoivia lehmiä.

Pihattonavettaan kannattaa hankkia nupoutettuja eläimiä. Mikäli sellaisia ei ole tarjolla, pitäisi sarvien katkaisun ja eläimen siirron tapahtua eri aikaan. Näin eläimelle ei aiheuteta monta stressiä yhdellä kertaa.

Kun eläinten hankinnassa on hyvissä ajoin liikkeellä, ei kiire pääse laajennuksen valmistuttua yllättämään. Eläimiä kannattaa hankkia niin, että laajennuksen valmistuttua navetta saadaan nopealla aikataululla täyteen tuotantoon eli lehmämäärä täysilukuiseksi. Automaattisessa lypsyjärjestelmässä tämä tarkoittaa vuotta. Robottinavetassa poikimisten täytyy jakautua tasaisesti vuoden ympäri, jotta robotin kapasiteetti tulee kaikkina aikoina täysin hyödynnetyksi.

Eläinten hankintaan kannattaa laatia budjetti. Haastattelussa eläinten hankinnan kokonaiskustannusten arviointi tuotti vaikeuksia. Tämä viittaa siihen, ettei budjettia ollut tai sitä ei ollut seurattu. Budjetin avulla on helpompi varautua eläinten ostohetkeen ja on todennäköisempää saada navetta nopeasti täyteen tuotantoon. Myös taloudelliset yllätykset ovat siten vähemmän todennäköisiä.

Panostus ostoeläinten laatuun kannattaa. Jo ennen eläinten hankinnan aloittamista kannattaa miettiä, millaisia eläimiä haluaa, ja minkälaiset eläimet menestyvät tulevassa navetassa. Eläimen laadun tietämiseksi tarvitsee myyntikarjan kuulua tuotosseurantaan. Eläimen polveutumistodistuksesta selviää sen jalostuksellinen taso.

Monet ostajat kiinnittävät nykyisin erityishuomiota eläimen ja sen vanhempien rakenteen periyttämiskykyyn ja lypsynopeuteen. Nämä ominaisuudet ovat erityisen tärkeitä automaattisessa lypsyjärjestelmässä, mutta niiden merkitystä ei voi väheksyä muissakaan isoissa yksiköissä. Haastatteluissa tuli esille käsitys holstein-friisiläisen rodun paremmuudesta automaattisessa lypsyjärjestelmässä lypsynopeuden ja paremman rakenteen suhteen. Niitä on kuitenkin tarjolla vähemmän. Valtaosa Suomen lypsylehmistä on ayrshirejä.

Laatuun panostaminen voi tarkoittaa myös alkiosiirron käyttöä eläinaineksen parantamisessa. Haastatteluissa tosin viitattiin stressaavan rakennusajan olevan huono ajankohta alkionsiirron aloittamiselle tai sen laajamittaiseen käyttöön laajentavalla tilalla. Joillakin haastattelutiloilla työvoimaa oli niin, että yksi pystyi keskittymään eläinaineksen hankintaan ja parantamiseen. Laajennuksen jälkeen alkionsiirto on erittäin perusteltua, jos halutaan nopeuttaa karjan perinnöllistä edistymistä. Alkioita voi siirtää jalostuksellisesti huonoihin tai muilta ominaisuuksiltaan tilan olosuhteisiin soveltumattomiin eläimiin. Silloin kantajasta ei jää jälkeläistä karjaan. Sukupuolilajitellun sperman käytöllä voidaan myös nopeuttaa jalostusta, koska hyvältä yksilöltä saadaan todennäköisemmin lehmävasikka kuin käyttämällä tavanomaista spermaa.

Oikeaa eläimen hankintaikää ei ole. Laajentavan tilan on ratkaistava, mitkä asiat ovat heille tärkeitä. Vasikoina eläinaineksen hankinnan tekevillä on etuna edullinen hankintahinta. Kasvattamalla eläimet itse saa ne mieleisikseen kapasiteetiltaan ja kooltaan. Niiden suhtautumiseen hoitajaan voi siinä vaiheessa vaikuttaa paljon. Samoin eläin oppii tuntemaan hoitajansa ja luottamaan häneen. Aikataulu on yleensä väljä vielä kaksi vuotta ennen laajennusta, joten vasikoita voi katsella ja etsiskellä kaikessa rauhassa.

Vasikkana eläinaineksensa hankkijan kannattaa miettiä kasvatuskustannuksia. Ne voivat nousta korkeiksi. Väliaikaistiloissa kasvattaminen voi olla raskasta niin hoitajille kuin eläimillekin. Kasvatuksen ulkoistaja voi saada kasvatuskustannukset alemmaksi, mutta menettää oman tuntumansa eläimiin. Siirrettäessä hyvin pieniä vasikoita toiseen karjaan voi eläimen vastuskyky joutua koville varsinkin, jos samaan aikaan tulee pieniä vasikoita monelta eri tilalta useammanlaista bakteerikantaa mukanaan.

Nuorien hiehojen ostajalle on paljon valinnanvaraa verrattuna sen ikäisten kysyntään. Vuosikkaat kestävät vasikkaa paremmin siirron, koska niiden oma vasta-ainetuotanto on parempi kuin vasikoilla. Edut ovat samanlaisia kuin vasikan ostajilla eli eläin ennättää tottua hoitajaan, ja kapasiteettiin pystyy vielä jonkin verran vaikuttamaan. Kasvatuskustannukset ja väliaikaisolosuhteet ovat vuosikkaiden hankkijan kriittisiä tekijöitä. 
Hiehojen ostaminen muutama kuukausi ennen poikimista on edullista, jos vertaa kasvatuskustannuksia. Hiehon tuotantokustannukset vaihtelevat noin 1500 eurosta 2400 euroon. Hiehojen keskihinta on noin 1500 euroa. Hiehoista on myös eniten tarjontaa Faba Jalostuksen välityksessä ja tiettävästi muutenkin. Hiehon kokoon tai kapasiteettiin ei juuri enää voi vaikuttaa. Luonteen muuttaminenkin vaatii pitkällistä koulutusta.

Lehmien ostaminen on sijoitusmielessä kannattavin ostos. Siitä alkaa heti siirtopäivästä lähtien kertyä tuottoa maitotuotoksen muodossa. Lehmien keskimääräiset hinnat ovat hiehojen hintoja alhaisemmat. Lehmän ostajan riskejä ovat eläimen sopeutuminen karjaan ja mahdolliset tarttuvat taudit kuten Staphylococcus aureus. Lehmä voi olla itse tartunnan levittäjä tai kuljetus- ja paikanvaihdosstressin takia heikomman vastuskyvyn omaavana alttiimpi sairastumaan toisten eläinten levittämiin tarttuviin tauteihin. Jos eläinaineksen hankinta jätetään lehmänä ostamiseksi, on yleensä jo kiire täyttää navetta. Silloin ostetaan mitä sattuu löytymään eikä laatuun ennätetä enää panostaa.

Laajentaneille tiloille tehdyn haastattelun tulosten perusteella hiehon ostajat ovat tyytyväisempiä kuin vasikan tai lehmän ostajat. Pieniä vasikoita tai lypsäviä lehmiä siirrettäessä erilaisiin olosuhteisiin on suurempi riski sopeutumisongelmiin ja sairauksiin kuin hiehoilla.

\section{Kirjallisuus}

Alasuutari, P. 1999. Laadullinen tutkimus. 3. uudistettu painos. Tampere, Vastapaino.

Hirsjärvi, S., Hurme, H. 2004. Tutkimushaastattelu. Helsinki, Yliopistopaino.

Huhtanen, P. \& Nousiainen, J. 2006. Dynaaminen karjamalli uudistuseläinten tarpeen laskentaan. Teoksessa MTT:n selvityksiä 112: Kestävä lehmä - Lypsylehmien poiston syyt ja kestävyyden taloudellinen merkitys. Toim. Heikkilä A. MTT Taloustutkimus. Helsinki, 41-47.

Jalostusnaudan markkinahinta. Maaseudun Tulevaisuus. 18.8.2008, 16.

Juntti, L., Heikkilä, A. 2006. Uudistushieho ei kasva ilmaiseksi. Nauta 3/2006, 28-29.

Kemppainen, M., ja Toroi, J., 2008. Hiehon kasvatuksen vaihtoehdot Case-tutkimus Maitoaho Ay:ssä. Opinnäytetyö. Savonia ammattikorkeakoulu. Iisalmi.

Lohenoja, S., 2008. Keskituotos lähes 8800 kiloa. Nauta 3/3008, 6-8.

Lotti, L. 1982. Markkinointitutkimus. Espoo. Weilin+Göösin kirjapaino.

Lounasheimo, L. 2007. Ystävyys helpottaa elämää. Koelypsy 4/2007, 6.

Mäntysaari, P. 2000. Hiehojen siemennystä edeltäneen ja tiineyden aikaisen kasvun yhteydet maidontuotantoominaisuuksiin. Pro gradu -työ. Helsingin Yliopiston kotieläintieteen laitoksen julkaisu 51. Helsinki.

Nousiainen, J. 2006. Lypsylehmien poiston syyt. Teoksessa MTT:n selvityksiä 112: Kestävä lehmä - Lypsylehmien poiston syyt ja kestävyyden taloudellinen merkitys. Toim. Heikkilä A. (2006). MTT: taloustutkimus. Helsinki, 9-26.

Parikka, P. 2006. Maidontuotantoon tarkoitettujen eläinten ja alkioiden kauppahintoja selittävät tekijät. Pro gradu -työ. Helsingin Yliopiston kotieläintieteen laitoksen julkaisuja 86. Helsinki.

Raussi, S. 2005. Group management of young dairy cattle in relation to animal behaviour and welfare. Agrifood Research Reports 71. Academic Dissertation: Helsingin yliopisto. 2005.

Rautala, H. 1996. Tavoitteena terve karja. Gummerus kirjapaino Oy. Jyväskylä.

Sairanen, A. 2007. Onko kestäville karjoille edellytyksiä? Maitomestarit tiedote 2/2007. Maito-Savo. Sonkajärvi, 6-7.

Toivakka, M., Mäntysaari, E. 2006. Sonnien kestävyysindeksien ennustaminen tuotanto-, hedelmällisyys-, terveys- ja rakenneominaisuuksien jalostusarvoilla. Teoksessa MTT:n selvityksiä 112. Kestävä lehmä - Lypsylehmien poiston syyt ja kestävyyden taloudellinen merkitys. Toim. Heikkilä A. (2006). MTT Taloustutkimus. Helsinki, 75-82.

Wesselink, W., 2008. Hollantilaiset rokottavat sinikielitautia vastaan. Nauta 4/2008, 32-33. 